\title{
Provision of health care actions and services for the management of HIV/AIDS from the users' perspective
}

\author{
OFERTA DE AÇÕES E SERVIÇOS DE SAÚDE PARA O MANEJO DO HIVIAIDS, SOB A \\ PERSPECTIVA DOS USUÁRIOS
}

\section{OFERTA DE ACCIONES Y SERVICIOS DE SALUD PARA EL MANEJO DEL VIH/SIDA, BAJO LA PERSPECTIVA DE LOS DROGADICTOS}

\author{
Luana A. Figueiredo', Lívia M. Lopes¹, Gabriela T. Magnabosco', Rubia Laine de P. Andrade ${ }^{2}$, \\ Mayara F. Faria ${ }^{3}$, Vanessa C. Goulart ${ }^{4}$, Lucia M. Scatena ${ }^{5}$, Jordana de A. Nogueira ${ }^{6}$, lone C. Pinto ${ }^{7}$, \\ Ricardo A. Arcencio ${ }^{8}$, Pedro F. Palha9 ${ }^{9}$ Tereza Cristina S. Villa ${ }^{10}$, Aline A. Monroe ${ }^{11}$
}

\begin{abstract}
Objective: To analyse the provision of health care actions and services for people living with AIDS and receiving specialised care in Ribeirão Preto, SP. Method: A descriptive, exploratory, survey-type study that consisted of interviews with structured questionnaires and data analysis using descriptive statistics. Results: The provision of health care actions and services is perceived as fair. For the 301 subjects, routine care provided by the reference team, laboratory tests and the availability of antiretroviral drugs, vaccines and condoms obtained satisfactory evaluations. The provision of tests for the prevention and diagnosis of comorbidities was assessed as fair, whereas the provisions of specialised care by other professionals, psychosocial support groups and medicines for the prevention of antiretroviral side effects were assessed as unsatisfactory. Conclusion: Shortcomings were observed in follow-up and care management along with a predominantly biological, doctor-centred focus in which clinical control and access to antiretroviral therapy comprise the essential focus of the care provided.
\end{abstract}

\section{DESCRIPTORS}

Acquired Immunodeficiency Syndrome Antiretroviral therapy, highly active Health Services

Comprehensive Health Care

Patient Care Team

\section{RESUMO}

Objetivo: Analisar a oferta de ações nos serviços de saúde que prestam assistência às pessoas que vivem com aids em acompanhamento nos serviços especializados do município de Ribeirão Preto-SP. Método: Estudo descritivo, exploratório, do tipo inquérito. Foram realizadas entrevistas com questionário estruturado e análise dos dados por meio de estatísticas descritivas. Resultados: A oferta de ações e serviços de saúde é vista como regular. Para os 301 sujeitos, o atendimento de rotina pela equipe de referência; exames laboratoriais e disponibilização de antirretrovirais, vacinas e preservativos obtiveram avaliação satisfatória. Avaliadas como regulares a oferta de exames para prevenção e diagnóstico de comorbidades, e insatisfatória a oferta de atendimento especializado por outros profissionais; de grupos de apoio psicossocial e medicamentos preventivos de efeito colateral dos antirretrovirais. Conclusão: Debilidades permeiam o acompanhamento e a gestão do cuidado, com predomínio do enfoque biologicista, médico-centrado, no qual o controle clínico e o acesso a Terapia Antirretroviral constituem-se como o foco essencial da assistência prestada.

\section{DESCRITORES \\ Síndrome da Imunodeficiência Adquirida Terapia antirretroviral de alta atividade Serviços de Saúde Assistência Integral à Saúde Equipe de Assistência ao Paciente}

\section{RESUMEN}

Objetivo: Analizar la oferta de acciones en los servicios de salud que prestan asistencia a las personas que viven con SIDA en el seguimiento de los servicios especializados del municipio de Ribeirão Preto-SP. Método: Estudo descriptivo, exploratorio, del tipo encuesta. Se llevaron a cabo entrevistas con cuestionario estructurado y análisis de datos por medio de estadísticas descriptivas. Resultados: La oferta de acciones y servicios de salud se la ve como regular. Para los 301 sujetos, la atención de rutina por el equipo de referencia; exámenes de laboratorio y facilitación de antirretrovirales, vacunas y preservativos obtuvieron evaluación satisfactoria. Evaluadas como regular la oferta de exámenes para la prevención y el diagnóstico de comorbilidades, e insatisfactoria la oferta de atención especializada por otros profesionales; de grupos de apoyo psicosocial y fármacos preventivos de efecto colateral de los antirretrovirales. Conclusión: Debilidades permean el seguimiento y la gestión del cuidado, con predominio del enfoque biologicista, centrado en el médico, en el que el control clínico y el acceso a la Terapia Antirretroviral se constituyen como el enfoque esencial de la asistencia prestada.

\section{DESCRIPTORES}

Síndrome de Inmunodeficiencia Adquirida Terapia antirretroviral altamente activa Servicios de Salud Atención Integral de la Salud Grupo de Atención al Paciente

\footnotetext{
${ }^{1}$ PhD Student, Graduate Program in Public Health Nursing, School of Nursing of Ribeirão Preto, University of São Paulo, Ribeirão Preto, state of São Paulo (SP), Brazil. 2 PhD, School of Nursing of Ribeirão Preto, USP, Ribeirão Preto, SP, Brazil. ${ }^{3}$ MS Student, Graduate Program in Public Health Nursing, School of Nursing of Ribeirão Preto, USP, Ribeirão Preto, SP, Brazil. ${ }^{4}$ Nurse, School of Nursing of Ribeirão Preto, USP, Ribeirão Preto, SP, Brazil. ${ }^{5}$ Adjunct Professor, Department of Social Medicine, Federal University of Triangulo Mineiro, Uberaba, state of Minas Gerais (MG), Brazil. ${ }^{6}$ Associate Professor, Department of Clinical Nursing, Federal University of Paraíba, João Pessoa, state of Paraíba (PB), Brazil. ${ }^{7}$ Associate Professor, Department of Maternal and Child Care and Public Health, School of Nursing of Ribeirão Preto, USP, Ribeirão Preto, SP, Brazil. ${ }^{8}$ PhD, Professor, Department of Maternal and Child Care and Public Health, School of Nursing of Ribeirão Preto, USP, Ribeirão Preto, SP, Brazil. ${ }^{9}$ Associate Professor, Department Maternal-Infant and Public Health, School of Nursing of Ribeirão Preto, USP, Ribeirão Preto, SP, Brazil. ${ }^{10}$ Full Professor, Department of Maternal and Child Care and Public Health, School of Nursing of Ribeirão Preto, USP, Ribeirão Preto, SP, Brazil. ${ }^{11}$ PhD, Professor, Department of Maternal and Child Care and Public Health, School of Nursing of Ribeirão Preto, USP, Ribeirão Preto, SP, Brazil.
} 


\section{INTRODUCTION}

Understanding the dynamics of diseases such as HIV/ AIDS goes beyond the mere determination of epidemiological rates because this understanding also includes the interface and interrelationships between the living conditions and socio-sanitary and political dynamics instituted in certain territories. These interrelationships lead to the emergence of population groups with different, complex and unique conditions of vulnerability that are under the responsibility of specialised care units. Accordingly, the conception of social changes and the new HIV/AIDS epidemic trends in Brazil ${ }^{(1-3)}$, which are linked to the development of the chronic-degenerative profile assumed by those with the disease, is increasingly more challenging for the health sector that aims to properly manage the disease.

From a theoretical perspective, although HIV/AIDS is an infectious and transmissible disease, it is characterised as a chronic condition ${ }^{(4-6)}$ because of its persistence over time, which requires an integrated health care network capable of providing a certain level of permanent and sustainable care via appropriate strategies for its prevention and management. It should be noted that the conception of the term management in the present study transcends the simplistic handling dimension that can be associated to its meaning because, from a systemic point of view, management encompasses the knowledge and technical, managerial and political skills necessary to transform the main demands of this population into consistent, optimised and assertive actions and services ${ }^{(7)}$.

Among the advances and political priorities set in the Brazilian scenario regarding the management of HIV/AIDS, the following should be highlighted: the guarantee of universal access to early diagnosis and timely treatment; the early identification of opportunistic events for appropriate clinical management; the improvement of current medications aimed at reducing adverse effects to contribute to the adherence of individuals affected by the disease to the therapeutic process and the expansion of preventive actions geared towards the community, especially vulnerable groups ${ }^{(7-8)}$.

However, positive effects on the quality of life of people living with HIV/AIDS (PLWHA) rely on a diversified, complex service network aimed at promoting health through clinical care in combination with diagnostic support ${ }^{(9)}$. In this sense, clinical care is beyond medical care, which often favours the control of HIV evolution in the body. From this perspective, interactions with other professionals could contribute to recognition of the needs of each individual, resulting in the provision of expanded and integrated $\operatorname{care}^{(9)}$.

In this context, there is an urgent need to strengthen the health care network and its professionals not just in management of the disease, which is biologically complex, but especially the perspective of the care provided to PLWHA and the biopsychosocial demands that emerge during the process of care-in other words, the professional-user interface.

Therefore, in Brazil the programmatic advances related to control of the HIV/AIDS epidemic seek to guarantee the provision of health care actions and services directed towards appropriate clinical management for PLWHA ${ }^{(10)}$. Given the above information, the present study aimed to analyse the provision of health care actions and services for PLWHA in an outpatient follow-up of patients with STD/AIDS in Ribeirão Preto, state of São Paulo (SP).

\section{METHOD}

This is a descriptive, exploratory survey-type study conducted in the municipality of Ribeirão Preto, SP, which had an estimated population of 614,759 inhabitants in $2011^{(11)}$. Health care in this municipality is divided into five health districts (North, South, Central, East and West), and each has a Specialised Care Service (Serviço de Assistência Especializada - SAE) in which the HIV/AIDS Program is integrated. Thus, care for the PLWHA is provided by services at the secondary and central levels by specialised teams that are also responsible for Home Care Therapeutic Services (Serviço de Assistência Domiciliar Terapêutica - SAD) and the Counselling and Testing Centres (Centros de Testagem e Aconselhamento - CTA). The municipality is also backed up by a University Hospital for the tertiary-level care of severe cases that require hospitalisation ${ }^{(12)}$.

The study population consisted of PLWHA that were being followed-up at the municipality's SAE. The following were used as inclusion criteria: confirmed AIDS cases with antiretroviral therapy (ART) established for more than six months; individuals living in Ribeirão Preto but not in the prison system and an age of 18 years or older. It is noteworthy that AIDS cases were defined as individuals who were diagnosed and receiving outpatient care, which fits the following criteria adopted by the Ministry of Health: advanced HIV infection with effects on the immune system with or without the occurrence of signs and symptoms caused by HIV itself or by consequent opportunistic infections (infections and cancer) ${ }^{(13)}$.

In January 2011, 1,389 cases were being followed in the municipality; of these, 249 were followed by the Central Outpatient Clinic, 249 by the North Outpatient Clinic, 374 by the West Outpatient Clinic, 374 by the South Outpatient Clinic and 143 by the East Outpatient Clinic. We opted to use the letters $A, B, C, D$ and $E$ to designate the specialised clinics of the STD/AIDS and Viral Hepatitis Program in the municipal health network to preserve the identity of the individuals. It is noteworthy that the five SAEs had heterogeneous configurations with respect to the composition of the reference teams, availability of other professions, building infrastructure (coupled or not with other health services), organisation of the physical space, schedule of operation (days/times/week), 
number of users being followed-up, consultations/day/ month, geographic location/accessibility and inclusion in health districts with different population profiles and areas of higher/lower social vulnerability. We then proceed to identify and characterise the scenarios using the tool Avaliação da Qualidade da Assistência Ambulatorial nos Serviços Públicos de Atenção à Aids no Brasil [Quality Assessment of Outpatient Care in the Public Service for the Care of AIDS in Brazil] as a guideline ${ }^{(14)}$.

To calculate the sample size, it was assumed that $95 \%$ of the estimates could differ from the unknown population value $P$ by at most $5 \%$, or the absolute value of $\alpha$ equal to 0.05 , for a confidence level of $95 \%$. A P value of 0.5 was adopted in advance. Thus, the minimum number of patients was determined using the expression $n^{*}=(P \times Q) / V(p)$, resulting in 384.16. The sample size $n$ was corrected for the population $(n=301)$ and a potential loss of $5 \%$, thus yielding 317 individuals to be approached for interview.

The sampling process was performed via proportionate stratification according to the health service that accompanied the case, and convenience sampling was performed. Thus, 54 individuals followed-up by Outpatient
Clinic $A, 54$ individuals by Reference Centre $B ; 81$ by Outpatient Clinic $C ; 81$ by Reference Centre $D$ and 33 by Outpatient Clinic $E$ were interviewed. It is noteworthy that 301 individuals could be included in the sample; 16 individuals refused to participate in the study with the main argument of a lack of time.

A structured questionnaire was used as a data collection tool and was prepared based on the following materials: Quality assessment of outpatient care in the public health services for AIDS in Brazil(14); Recommendation of the Ministry of Health for ART in HIV-infected adults ${ }^{(7)}$, outpatient follow-up protocol for patients with HIV/AIDS from the Hospital Foundation of Minas Gerais $^{(15)}$ and Methodology for rapid assessment of the organisational characteristics and performance of primary care services in the National Health System (Sistema Único de Saúde - SUS) ${ }^{(16)}$.

From this questionnaire, variables related to the provision of health care actions and services were selected conceptually, based on the list of services ${ }^{(17)}$ (Chart 1). These variables contained a range of pre-set options (Likert) with values ranging from one to five, with the most favourable response corresponding to the highest value.

Chart 1 - Health care provision variables used in the study according to the data collection instrument and responses categories section, Ribeirão Preto, 2012

\begin{tabular}{|c|c|c|}
\hline $\begin{array}{l}\text { Provision of health care actions } \\
\text { and services }\end{array}$ & Variables & Response categories* \\
\hline \multirow{9}{*}{$\begin{array}{l}\text { Routine and supplementary care } \\
\text { by the reference team responsible } \\
\text { for follow-up }\end{array}$} & V1- Routine medical consultation & () $1 \quad() 2 \quad() 3 \quad() 4 \quad() 5$ \\
\hline & V2-Consultation with nursing staff & () 1 () 2 () 3 () 4 () 5 \\
\hline & V3-Consultation in the event of complications & () $1 \quad() 2 \quad() 3 \quad() 4 \quad() 5$ \\
\hline & V4- Psychological support & () $1 \quad() 2 \quad() 3 \quad() 4 \quad() 5$ \\
\hline & V5- Evaluation of hearing function & () $1 \quad() 2 \quad() 3 \quad() 4 \quad() 5$ \\
\hline & V6- Dermatological evaluation & () $1 \quad() 2 \quad() 3 \quad() 4 \quad() 5$ \\
\hline & V7- Home visit & () $1 \quad() 2 \quad() 3 \quad() 4 \quad() 5$ \\
\hline & V8- Support group & () $1 \quad() 2 \quad() 3 \quad() 4 \quad() 5$ \\
\hline & V9- Evaluation of health status of partner/family members & () $1 \quad() 2 \quad() 3 \quad() 4 \quad() 5$ \\
\hline \multirow{6}{*}{$\begin{array}{l}\text { Supplementary care by multidis- } \\
\text { ciplinary teams of other health } \\
\text { services }\end{array}$} & V10- Psychologist/psychiatric support & () $1 \quad() 2 \quad() 3 \quad() 4 \quad() 5$ \\
\hline & V11- Social worker support & () $1 \quad() 2 \quad() 3 \quad() 4 \quad() 5$ \\
\hline & V12- Gynaecological care & () 1 () 2 () $3 \quad($ ) 4 () 5 \\
\hline & V13-Dental care & () $1 \quad() 2 \quad() 3 \quad() 4 \quad() 5$ \\
\hline & V14- Hearing evaluation with speech therapist & $($ () $1 \quad() 2 \quad() 3 \quad() 4 \quad() 5$ \\
\hline & V15-Dermatological evaluation with dermatologist & () 1 () 2 () 3 () 4 () 5 \\
\hline \multirow{9}{*}{$\begin{array}{l}\text { Guidelines by the reference team } \\
\text { responsible for following up the } \\
\text { cases }\end{array}$} & V16- Participation in non-governmental organisations & () 1 () 2 () 3 () 4 () 5 \\
\hline & V17- In regards to family planning & () 1 () 2 () 3 () 4 () 5 \\
\hline & V18- In regards to sexuality and condom use & () 1 () 2 () 3 () 4 () 5 \\
\hline & V19- In regards to food and nutrition & () 1 () 2 () 3 () 4 () 5 \\
\hline & V20- In regards to the proper use of medication & () 1 () 2 () 3 () 4 () 5 \\
\hline & V21- In regards to the side effects and use of medication & () 1 () 2 () 3 () 4 () 5 \\
\hline & V22- In regards to the use of alcohol, tobacco and other drugs & () $1 \quad() 2 \quad() 3 \quad() 4 \quad() 5$ \\
\hline & $\begin{array}{l}\text { V23- In regards to the criteria and procedure for applying for government } \\
\text { benefits }\end{array}$ & () 1 () 2 () 3 () 4 () 5 \\
\hline & V24- In regards to vaccines & () 1 () 2 () 3 () 4 () 5 \\
\hline
\end{tabular}


Continuation

\begin{tabular}{|c|c|c|}
\hline $\begin{array}{l}\text { Provision of health care actions } \\
\text { and services }\end{array}$ & Variables & Response categories* \\
\hline \multirow{5}{*}{$\begin{array}{l}\text { Supplies by the reference team } \\
\text { responsible for following up the } \\
\text { cases }\end{array}$} & V25- Vaccines & () $1 \quad() 2 \quad() 3 \quad() 4 \quad() 5$ \\
\hline & V26-Antiretroviral drugs & () $1 \quad() 2 \quad() 3 \quad() 4 \quad() 5$ \\
\hline & $\begin{array}{l}\text { V27- Medications to prevent or lessen the side effects of antiretroviral } \\
\text { therapy }\end{array}$ & () 1 () 2 () 3 () 4 () 5 \\
\hline & V28-Medications to prevent opportunistic infections & () $1 \quad() 2 \quad() 3 \quad() 4 \quad() 5$ \\
\hline & V29-Condoms & () $1 \quad() 2 \quad() 3 \quad() 4 \quad() 5$ \\
\hline \multirow{5}{*}{$\begin{array}{l}\text { Request for tests by the reference } \\
\text { team responsible for following } \\
\text { up the cases }\end{array}$} & V30-Tests for CD4+ T lymphocyte counts & () $1 \quad$ () $2 \quad$ () $3 \quad$ () $4 \quad$ () 5 \\
\hline & V31- Tests to assess viral load & () $1 \quad$ ()2 () $3 \quad$ () $4 \quad$ () 5 \\
\hline & V32- Request for X-ray based on symptoms suggestive of tuberculosis & () $1 \quad() 2 \quad() 3 \quad() 4 \quad() 5$ \\
\hline & $\begin{array}{l}\text { V33- Request for sputum examination based on symptoms suggestive of } \\
\text { tuberculosis }\end{array}$ & () 1 () 2 () 3 () 4 () 5 \\
\hline & V34- Tuberculin test (annually) & () $1 \quad$ () 2 () 3 () 4 () 5 \\
\hline
\end{tabular}

Note: *A Likert scale was used with values ranging from one to five, with the responses corresponding to: $1=$ Never; $2=$ Almost never; $3=$ Sometimes; $4=$ Almost always; 5 = Always.

Data collection was conducted from July 2011 to February 2012. The interviews were conducted at the clinics after the participants signed an Informed Consent Form.

The collected data were analysed using Statistica software version 9.0 from Statsoft (Dell, Inc., Round Rock, TX, USA). To analyse the provision of health care actions and services to PLWHA, the mean value was calculated from all the responses to each indicator in the list of services category and was designated the Composite Indicator $(\mathrm{Cl})$ for the provision of health care actions and services for the municipality and for each SAE. Next, indicators were developed from the variables selected for the study. The developed indicator corresponded to the mean value obtained by the sum of all responses from all respondents for each question and divided by the total number of respondents; these indicators were categorised as satisfactory (mean values near 4 and 5), fair (mean value near 3) or unsatisfactory (mean values near 1 and 2).

This study was approved by the Ethics Committee of the School of Nursing of Ribeirão Preto, University of São Paulo (Universidade de São Paulo - USP) under protocol No. $1215 / 2010$.

\section{RESULTS}

From the sum of the mean values of all indicators in the list of services category, the $\mathrm{Cl}$ was calculated for the provision of health care actions and services and yielded an overall mean of 3.32 , or a classification of fair in the studied municipality.

Similarly, the $\mathrm{Cl}$ was calculated for each outpatient clinic in the municipality; the mean values per clinic were as follows: $A=3.40 ; B=3.43 ; C=3.02 ; D=3.54$ and $E=3.23$. Little variability was observed between the $C l s$, with classifications of fair in four of the five clinics (A, B, $C$ and $E$ ) and one clinic (D) receiving a satisfactory classification, albeit with a mean value similar to the other clinics. The clinic with the lowest mean value for the provision of health care actions and services to PLWHA was $\mathrm{C}$.

According to the 301 individuals interviewed regarding the provision of routine and supplementary care by the reference team responsible for following up the cases, the indicators of the provision of routine medical and nursing consultation were better assessed and exhibited satisfactory performance together with the indicators consultation in the event of complications and dermatological evaluation. The indicators provision of psychological support, evaluation of hearing function, home visits, evaluation of health status of the partner/ family members and the provision of support groups were regarded as unsatisfactory, with the latter exhibiting the worst performance (Table 1).

Table 1 - Distribution of the means and confidence intervals of variables in the list of services category related to the provision of routine and supplementary care by the reference team responsible for following up the cases, Ribeirão Preto, SP, July 2001 to February 2012

\begin{tabular}{lcc}
\hline Provision variable & Mean & Confidence interval \\
\hline Routine medical consultation & 4.97 & $4.94-4.99$ \\
Consultation with nursing staff & 4.84 & $4.76-4.92$ \\
Consultations in the event of complications & 3.90 & $3.73-4.09$ \\
Psychological support & 3.55 & $3.35-3.76$ \\
Evaluation of hearing function & 1.67 & $1.51-1.84$ \\
Dermatological evaluation & 3.09 & $2.87-3.29$ \\
Home visit & 1.25 & $1.15-1.35$ \\
Support groups & 2.63 & $2.43-2.82$ \\
Evaluation of health status of the partner/family members & 2.38 & $2.17-2.58$ \\
\hline
\end{tabular}


Regarding the provision of specialised care in other health services, most indicators had unsatisfactory ratings except for gynaecological care, which was considered satisfactory. It is noteworthy that although among the respondents $50.8 \%$ were female and the gynaecological care was often offered by two SAEs, a low percentage of users used the municipality's basic health care network for such care (3.0\%).

Among the indicators classified as unsatisfactory, the provision of hearing evaluation with a speech therapist received the worst rating (Table 2 ).

Table 2 - Distribution of the means and confidence intervals of variables in the list of services category related to the provision of supplementary care by multidisciplinary teams of other health care services, Ribeirão Preto, SP, July 2011 to February 2012

\begin{tabular}{lcc}
\hline Provision variable & Mean & Confidence interval \\
\hline Psychologist/psychiatrist support & 2.23 & $2.04-2.42$ \\
Social worker support & 2.57 & $2.04-2.77$ \\
Gynaecological care & 4.11 & $2.04-4.35$ \\
Dental care & 2.30 & $2.04-2.49$ \\
Evaluation of hearing function with a speech therapist & 1.13 & $2.04-1.21$ \\
Dermatological evaluation with a dermatologist & 1.91 & $1.73-2.08$ \\
\hline
\end{tabular}

Regarding the provision of guidelines by the reference team, most indicators were considered satisfactory; however, the provision of relevant information related to non-governmental organisations active in the municipality, family planning guidelines and criteria and procedures for applying for public benefits were rated as unsatisfactory (Table 3).

Table 3 - Distribution of the means and confidence intervals of variables in the list of services category related to the provision of guidance by the reference team responsible for following up the cases, Ribeirão Preto, SP, July 2011 to February 2012

\begin{tabular}{|c|c|c|}
\hline Provision variable & Mean & Confidence interval \\
\hline For participation in NGOs & 2.07 & $1.90-2.24$ \\
\hline In regards to family planning & 1.94 & $1.75-2.13$ \\
\hline In regards to sexuality and condom use & 4.46 & $4.32-4.59$ \\
\hline In regards to food and nutrition & 3.94 & $3.76-4.13$ \\
\hline In regards to the proper use of medications & 4.87 & $4.81-4.93$ \\
\hline In regards to use of alcohol, tobacco and other drugs & 4.07 & $3.80-4.24$ \\
\hline In regards to apply for government benefits & 2.55 & $2.34-2.75$ \\
\hline In regards to vaccines & 4.72 & $4.62-4.82$ \\
\hline
\end{tabular}

Regarding the health supplies offered by the reference team, indicators related to the provision of vaccines, antiretroviral drugs and condoms were rated satisfactory, whereas those related to the provision of medication to prevent or minimise side effects of ART and the onset of opportunistic diseases were considered unsatisfactory (Table 4).

Table 4 - Distribution of the means and confidence intervals of variables in the list of services category related to the provision of supplies by the reference team responsible for following up the cases, Ribeirão Preto, SP, July 2011 to February 2012

\begin{tabular}{llc}
\hline Provision variable & Mean & Confidence interval \\
\hline Vaccines & 4.70 & $4.59-4.80$ \\
Antiretroviral drugs & 4.89 & $4.83-4.96$ \\
Medications to prevent the side effects of Antiretroviral Therapy & 2.32 & $2.12-2.52$ \\
Medications to prevent opportunistic diseases & 2.28 & $2.08-2.48$ \\
Condoms & 4.86 & $4.79-4.94$ \\
Sobre efeito colateral e uso dos medicamentos & 4.31 & $4.16-4.46$ \\
\hline
\end{tabular}

Indicators related to the provision and request of blood tests according to case management protocols (CD4+ T lymphocyte and viral load counts) were considered satisfactory. Regarding the provision of tests upon the presence of signs and symptoms suggestive of tuberculosis (TB), indicators related to the provision/request for X-ray and tuberculin tests were rated as fair, whereas that related to the provision/request for sputum culture was rated as unsatisfactory; in other words, this test was never or almost never requested (Table 5). It is worth noting that $17 \%$ and $6.5 \%$ of respondents reported feeling that X-ray tests and sputum examination, respectively, were necessary because of the presence of signs/ symptoms compatible with TB. 
Table 5 - Distribution of the means and confidence intervals of variables in the list of services category related to the provision and request of tests by the reference team responsible for following up the cases, Ribeirão Preto, SP, July 2011 to February 2012

\begin{tabular}{lcc}
\hline Provision variables & Mean & Confidence interval \\
\hline Tests for CD4+ T lymphocyte counts & 4.96 & $4.93-4.98$ \\
Tests to assess viral load & 4.96 & $4.93-4.98$ \\
X-ray upon tuberculosis symptoms & 3.25 & $3.04-3.45$ \\
Sputum examination upon symptoms of tuberculosis & 2.43 & $2.23-2.63$ \\
Tuberculin test (annually) & 3.22 & $3.023-3.43$ \\
\hline
\end{tabular}

\section{DISCUSSION}

The results of the present study suggest that the overall provision of health care actions and services to PLWHA by the SAEs of the municipality is perceived as fair, regardless of the clinic.

It was observed that in the scope of such actions, there is a prevalent focus on the provision of clinical-biological activities that involve stabilising the disease in the individual and preventing the spread of the virus. Thus, the satisfactory evaluations by the subjects regarding indicators related to the provision of routine medical and nursing consultations and consultations in the event of complications (Table 1), supplies such as ARV drugs, vaccines, and condoms (Table 4) and blood tests (Table 5) reveals the maintenance of adequate clinical disease management for those individuals who were being followed up.

However, gaps exist in measures related to holistic care of the user, as the study revealed that the provision of health care actions and services related to other health needs and demands as well as the clinical and pharmacological approach to the disease, including the diagnosis and management of opportunistic diseases, were rated as unsatisfactory (Tables 4 and 5).

TB is thought to be the primary opportunistic infection affecting PLWHA ${ }^{(18)}$. The interaction between TB and HIV increases the infection rates for both diseases; therefore, an integration between the two programs for the provision of diagnostic and preventive actions against both TB and HIV lead to improved user access to holistic care, thus favouring the control of both diseases ${ }^{(19)}$. However, in the present study, the provision of X-ray and Tuberculin tests was irregular, and the request for sputum culture for TB control and prevention was rated as unsatisfactory in this population (Table 5). It is important to note that when considering the provision of care to PLWHA, the incidence and prevalence of the main comorbidities should also be considered. It should be noted, however, that despite the high prevalence of co-infection in the municipality, with recorded values near $30 \%$ in recent years ${ }^{(20)}$, practices related to disease prevention and control are hardly considered by the team during case follow-up.

The team compositions of the SAEs in the municipality differ according to a contextual analysis. Regarding the nursing staff, all clinics had assistants/technicians during all periods; however, with respect to nurses, only two SAEs had professionals dedicated exclusively to the program, and one SAE had no full-time nurses. In other units, these professionals split their time with other service demands, such as involvement in other programs and administrative duties, among others. It is also noteworthy that the nursing consultation considered by the subjects of this study in these SAEs refers to both preand post-medical care, with actions aimed at evaluating the subjects' weight, height and blood pressure and the scheduling of tests and return visits.

Regarding the complexity of the disease, the focus of the care provided to PLWHA should be interdisciplinary (Table 2) because the trajectory of the disease imposes situations that are complicated, threatening and require difficult management, including stigma and discrimination, complex medication regimens, difficulties with treatment adherence, side effects and implications for sexual and reproductive life, among others ${ }^{(8)}$.

In the present study, the supply of medication to prevent the side effects of ARV was rated as unsatisfactory (Table 4). ART is known to induce harmful side effects in patients, including nausea, diarrhoea, vomiting, increased serum cholesterol and triglyceride levels and lipodystrophy ${ }^{(21)}$; these hinder adherence to treatment and maintenance of therapeutic success. Therefore, given the current chronicity of HIV/AIDS, minimisation of the side effects also implies improved treatment adherence and, consequently, an improved quality of life of PLWHA.

For this purpose, the professional team should be prepared to recognise the different health needs of this population and coordinate the provision of health care actions and services provided by the SAEs or other health care institutions ${ }^{(20)}$.

The unsatisfactory ratings from users for indicators such as psychosocial support, home visits, support groups (Table 1), information regarding participation in NGOs (Table 3) and other specialised care services, and social, dental, dermatology and speech pathologist care (Table 2) reflect the weaknesses of the SAE teams in terms of providing care from the health services network for the appropriate management of HIV/AIDS, even when the municipality receives assistance from NGOs in various social and health areas, such as psychological support to PLWHA and their families, STD/HIV/AIDS preventive work, 
and professional services in physical therapy, social work, psychology and shelter.

At all SAEs, an infectious diseases physician was present for at least one period of the day; however, regarding pharmaceutical care and social service, one SAE had no pharmacist/pharmacy assistants and two lacked social workers. In addition, when such professionals were present in health teams, they did not work only in the outpatient clinics to meet all of the demands of the Units. None of the outpatient clinics included the presence of a psychologist and/or speech therapist, a factor that hindered the provision of multi-professional care and weakened the interdisciplinary approach.

Therefore, it has been observed that the provision of health care actions and services to individuals with AIDS is grounded in a technological organisation that mirrors a medical care model centred on aspects that are not always consistent with the health needs of the users ${ }^{(22)}$.

Following this logic, it becomes obvious that although the specialised team provides treatment, it hardly explores the dimension of care because of the overload and unique responsibility of following up cases in the health care network ${ }^{(23)}$. The limitation of the health care service in this phase of care results in a disjointed service that attends to emerging and unique demands, resulting in fragmented care, leaving the individual vulnerable to preventable diseases, reinforcing the demand for emergency services, interfering with the patient's quality of life and, in extreme cases, possibly decreasing the amount of time between the onset of disease and death ${ }^{(17) .}$

It should be noted that the disease specificity should not be disregarded. The medical professional with disease specialisation is a critical resource for the maintenance of care. However, the results of the present study clarify that the provision of care that is based on and structured by a single professional leads to overload, thus hindering the professional's ability to meet all of the demands required by PLWHA.

Accordingly, strategies to enhance the work of professionals as well as multidisciplinary and interdisciplinary work and to aggregate and articulate new knowledge from distinct professionals to the health service are needed; these would be guided by the logic of integrated teamwork, with professionals trained to address the use of technology focused on interpersonal relationships in the pursuit of developing joint actions intended to solve the demands and needs resulting from a chronic disease ${ }^{(24-25)}$.

\section{REFERENCES}

1. Santos NJS, Buchalla CM, Filipe EV, Bugamelli L, Garcia S, Paiva V. Mulheres HIV positivas, reproduçãoe sexualidade. RevSaúdePública [Internet]. 2002 [citado 2013 maio 02];36(4):12-23. Disponível em: http://www.scielosp.org/pdf/rsp/v36n4s0/11159.pdf
The technological complexity that occurs during care refers to interactions among individuals, the organisation of work, exercise of the interdisciplinarity present in teamwork and continuous incorporation of new knowledge and practices in health care. The comprehensiveness of health care activities depends on the quality of these different dimensions of health work ${ }^{(26)}$. In a previous study conducted in the United States, it was observed that the health information technology used within a health professional team and among different teams and between professionals and patients constitutes a fundamental tool for the coordination and integration of the provided care. Moreover, its use is associated with improved HIV infection-related response rates due to adherence to and monitoring of treatment, thus resulting in increased viral suppression, cases with low viral detection levels and consequently an increased quality of life ${ }^{(27)}$.

The differences in the adopted healthcare practices are closely related to the indicators of satisfaction, treatment adherence and favourable laboratory results. In other words, integral and integrated care that is planned and executed over time rather than episodically may lead to more plausible results that exceed the estimates expected by HIV control programs ${ }^{(28)}$. Therefore, there is an urgent need for the constant transformation of essentially reactive, fragmented and episodic systems to respond to the demands of acute conditions and events by providing a system that is proactive, integrated, continuous and focused on the promotion and maintenance of health ${ }^{(6)}$.

\section{CONCLUSION}

The present study showed that the overall provision of health care actions and services to PLWHA by the SAES in Ribeirão Preto was classified as fair. However, the provisions related to the needs and demands of health care beyond a clinical and pharmacological approach to the disease received unsatisfactory ratings.

Thus, this study identified weaknesses that permeate the systematic monitoring and management of care provided to PLWHA through a predominantly biological-focused, physician-centred model in which clinical control and access to ART comprise the main focus of care provided. Despite scientific and technological advances, challenges are faced by the health care services and professionals who combat HIV/AIDS; these involve not only to ensuring universal and free access to diagnosis and drug treatment but, above all, advancing the development of comprehensive, integrated and assertive care consistent with the real needs of individuals, given the complexity of this disease and its chronicity.

2. Pinto ACS, Pinheiro PNC, Vieira NFC, Alves MDS. Compreensão da pandemia da AIDS nos últimos 25 anos. J Bras Doenças Sex Transm [Internet]. 2007 [citado 2013 maio 02];19(1):45-50. Disponível em: http://www.dst.uff.br//revista19-1-2007/7.pdf 
3. Pottes FA, Brito AM, Gouveia GC, Araújo EC, Carneiro RM. AIDS e envelhecimento: características dos casos com idade igual ou maior que 50 anos em Pernambuco, de 1990 a 2000. Rev Bras Epidemiol. 2007;10(3):338-51.

4. Organización Mundial de la Salud. Informe sobre la Salud en el Mundo, 2003. Forjemos el futuro [Internet]. Ginebra: OMS; 2003 [citado 2013 maio 02]. Disponible en: http://www.who. int/whr/2003/en/whr03_es.pdf?ua=1

5. Mendes EV. A atenção primária à saúde no SUS. Fortaleza: Escola de Saúde Pública do Ceará; 2002.

6. Mendes EV. As Redes de Atenção à Saúde. Belo Horizonte: Escola de Saúde Pública do Estado de Minas Gerais; 2009.

7. Brasil. Ministério da Saúde; Secretaria de Vigilância em Saúde. Programa Nacional de DST e AIDS. Recomendações para terapia anti-retroviral em adultos infectados pelo HIV. 7a ed. Brasília; 2008.

8. Souza TRC. Impacto psicossocial da AIDS: enfrentando perdas... ressignificando a vida. São Paulo: Centro de Referência e Treinamento DST/AIDS; 2008.

9. Fonseca AF. Políticas de HIV/AIDS no Sistema Único de Saúde: uma busca pela integralidade da atenção. In: Fundação Oswaldo Cruz; Escola Politécnica de Saúde Joaquim Venâncio. Textos de apoio em políticas de saúde. Rio de Janeiro: FIOCRUZ; 2005. p.183-205.

10. Galvão J. AIDS no Brasil: a agenda de construção de uma epidemia. São Paulo: Editora 34; 2000.

11. Fundação Sistema Estadual de Análise de Dados. População e estatísticas vitais: perfil municipal [Internet]. São Paulo: SEADE; 2014 [citado 2014 abr. 12]. Disponível em: http:// www.seade.gov.br/produtos/perfil/perfilMunEstado.php

12. Ribeirão Preto. Secretaria Municipal de Saúde. Programa Municipal de DST/AIDS e Hepatites Virais [Internet]. Ribeirão Preto; 2014 [citado 2014 maio 09]. Disponível em: http://www.ribeiraopreto.sp.gov.br/ssaude/programas/ aids/i16indice.php

13. Brasil. Ministério da Saúde; Secretaria de Vigilância em Saúde. Guia de Vigilância Epidemiológica. 6ạ ed. Brasília; 2005.

14. Brasil. Ministério da Saúde; Secretaria de Vigilância em Saúde, Departamento DST, AIDS e Hepatites Virais. Avaliação da qualidade da assistência ambulatorial nos serviços públicos de atenção à AIDS no Brasil [Internet]. Brasília; 2010 [citado 2014 maio 09]. Disponível em: http://sistemas. aids.gov.br/qualiaids/Questionario_Qualiaids_WEB.pdf

15. Fundação Hospitalar do Estado de Minas Gerais. Protocolo de Acompanhamento Ambulatorial do Paciente com HIV/ AIDS [Internet]. Belo Horizonte; 2013 [citado 2014 abr. 12]. Disponível em: www.fhemig.mg.gov.br/pt/protocolos-clinicos
16. Almeida CM, Macinko J. Validação de uma metodologia de avaliação rápida das características organizacionais e do desempenho dos serviços de atenção básica do Sistema Único de Saúde (SUS) em nível local. Brasília: OPAS; 2006.

17. Starfield B. Atenção primária: equilíbrio entre necessidades de saúde, serviços e tecnologia. Brasília: Ministério da Saúde; 2002.

18. World Health Organization. Global tuberculosis control: surveillance, planning, financing. Geneva; 2004. (WHO/HTM/ TB/2004.331).

19. Ansa GA, Walley JD, Siddiqi K, Wei X. Delivering TB/HIV services in Ghana: a comparative study of service delivery models. Trans R Soc Trop Med Hyg. 2014;108(9):560-7.

20. Brunello MEF, Chiaravalloti Neto F, Arcêncio RA, Andrade RLP, Magnabosco GT, Villa TCS. Áreas de vulnerabilidade para co-infecção HIV-AIDS/TB em Ribeirão Preto, SP. Rev Saúde Pública. 2011;45(3):556-63.

21. Rachid M, Schechter M. Manual de HIV/AIDS. 8a ed. Rio de Janeiro: Revinter; 2005.

22. Mendes EV. O cuidado das condições crônicas na atenção primária à saúde: o imperativo da consolidação da Estratégia da Saúde da Família. Brasília: OPAS; 2012.

23. Santos SMJ, Nobrega MML. Ações de enfermagem identificadas no Projeto CIPESC e utilizadas no cuidado de pacientes com AIDS. Rev Esc Enferm USP. 2004;38(4):369-78.

24. Borges MJ, Sampaio AS, Gurgel IG. Trabalho em equipe e interdisciplinaridade: desafios para a efetivação da integralidade na assistência ambulatorial às pessoas vivendo com HIV/Aids em Pernambuco. Ciênc Saúde Coletiva [Internet]. 2012 [citado 2013 maio 02];17(1):147-56. Disponível em: http://www.scielo.br/pdf/csc/v17n1/a17v17n1.pdf

25. Peduzzi M. Trabalho em equipe de saúde no horizonte normativo da integralidade, do cuidado e da democratização das relações de trabalho. In: Pinheiro R, Barros ME, Mattos RA. Trabalho em equipe sob o eixo da integralidade: valores, saberes e práticas. Rio de Janeiro: CEPESC; 2007. p. 161-77.

26. Nemes MIB, Castanheira ERL, Melchior R, Alves MTSSB, Basso $C R$. Avaliação da qualidade da assistência no programa de AIDS. Cad Saúde Pública [Internet]. 2004 [citado 2013 maio 02];20(2 Supl):310-21. Disponível em: http://www. scielo.br/pdf/csp/v20s2/24.pdf

27. Shade SB, Steward WT, Koester KA, Chakravarty D, Myers JJ. Health information technology interventions enhance care completion, engagement in HIV care and treatment, and viral suppression among HIV-infected patients in publicly funded settings. J Am Med Inform Assoc. 2014 July 16. [Epub ahead of print]

28. Torian LV, Xia Q, Wiewel EW. Retention in care and viral suppression among persons living with HIV/AIDS in New York City, 2006-2010. Am J Public Health. 2014;104(9):24-9. 